\title{
Chryseobacterium hominis sp. nov., to accommodate clinical isolates biochemically similar to CDC groups II-h and II-C
}

\author{
Mario Vaneechoutte, ${ }^{1}$ Peter Kämpfer, ${ }^{2}$ Thierry De Baere, ${ }^{1}$ \\ Véronique Avesani, ${ }^{3}$ Michèle Janssens ${ }^{3}$ and Georges Wauters ${ }^{3}$ \\ ${ }^{1}$ Department of Clinical Chemistry, Microbiology and Immunology, University of Ghent, Ghent, \\ Belgium \\ ${ }^{2}$ Institut für Angewandte Mikrobiologie, Justus-Liebig-Universität Giessen, Germany \\ ${ }^{3}$ Microbiology Unit, Faculty of Medicine, University of Louvain, Brussels, Belgium
}

Correspondence

Mario Vaneechoutte

Mario.Vaneechoutte@UGent.be
The family Flavobacteriaceae, emended by Bernardet et al. (2002), currently comprises more than 50 genera, including Bergeyella, Chryseobacterium, Elizabethkingia, Kaistella, Riemerella, Sejongia and the recently described Wautersiella (Kämpfer et al., 2006).

At present, the genus Chryseobacterium comprises 20 species, including some of clinical importance (Quan et al., 2007). In addition, Schreckenberger et al. (2003) mentioned a number of phenotypically related strains called 'CDC groups II-c, II-e, II-g, II-h and II-i', which are recovered rarely from clinical material, according to the authors. CDC group II-h and group II-c strains are distinguished from each other by acid production from sucrose (CDC group II-c), from group II-e by aesculin hydrolysis, from group II-i by the absence of xylose acidification and from group II-g because the latter is nonsaccharolytic. In this study, we characterized seven CDC II$\mathrm{h}$ and four CDC II-c strains, of which the clinical and geographical origin and the year of isolation are listed in

Abbreviation: tDNA-PCR, tRNA intergenic length polymorphism analysis. The GenBank/EMBL/DDBJ accession numbers for the 16S rRNA gene sequences of C. hominis are AM261868 and AM423079-AM423088.
Table 1. On the basis of this study, we propose that the 11 strains represent a novel species in the genus Chryseobacterium, for which the name Chryseobacterium hominis sp. nov. is proposed.

Biochemical and morphological tests were performed as described previously (Laffineur et al., 2002; Schreckenberger et al., 2003); the morphological characteristics of the novel species are given in the species description. Inhibition zones were determined on tryptic soy agar around discs of tetracycline $(30 \mu \mathrm{g})$, ciprofloxaxcin $(5 \mu \mathrm{g})$, trimethoprim/cotrimoxazole $(23.75 \mu \mathrm{g} / 1.25 \mu \mathrm{g})$, ampicillin $(10 \mu \mathrm{g})$, temocillin $(30 \mu \mathrm{g})$, cephalothin $(30 \mu \mathrm{g})$, cefotaxime $(30 \mu \mathrm{g})$, erythromycin $(15 \mu \mathrm{g})$, gentamicin $(10 \mu \mathrm{g})$ and colistin $(10 \mu \mathrm{g})$.

Acid production from carbohydrates was tested on oxidation-fermentation medium and low-peptone phenol red agar as described for ethylene glycol (Wauters et al., 1998). Assimilation-alkalinization of organic compounds was detected on Simmons' citrate agar base, replacing citrate by $0.2 \%(\mathrm{w} / \mathrm{v})$ of various organic substrates, according to Martin et al. (1981). Enzymic reactions were carried out by using diagnostic tablets from Rosco. The $\mathrm{KOH}$ test was used to detect flexirubin pigments (Bernardet et al., 2002). Susceptibility to antibiotics was 
Table 1. Data regarding clinical and geographical origin and phenotypic and genotypic data of the C. hominis strains studied

\begin{tabular}{|lrlc|}
\hline Strain designation & CDC group & \multicolumn{1}{c|}{ Origin and year of isolation } & Sequence similarity \\
\hline NF802 ${ }^{\mathrm{T}}$ & II-h & Blood, La Louvière, Belgium, 1998 & NA \\
NF1335 & II-h & Dialysis fluid, Brussels, Belgium, 1982 & 99.8 \\
NF675 & II-c & Blood, La Louvière, Belgium, 1995 & 99.9 \\
NF690 & II-c & Blood, La Louvière, Belgium, 1995 & 99.9 \\
NF974 & II-c & Blood, La Louvière, Belgium, 2001 & 99.8 \\
NF696 & II-h & Pus, Brussels, Belgium, 1995 & 100.0 \\
NF1141 & II-h & Blood, Brussels, Belgium, 2003 & 99.8 \\
NF1146 & II-h & Blood, Yvoir, Belgium, 2003 & 99.5 \\
CCUG 13649, CDC A6180 & II-h & Infraorbital drain, CA, USA, 1966 & 98.9 \\
CCUG 15261, CDC F4158 & II-h & Eye, MD, USA, 1984 & 99.9 \\
CCUG 36748, CDC 9064 & II-c & Aortic valve, CO, USA, 1963 & 99.9 \\
\hline
\end{tabular}

${ }^{\star} 16 \mathrm{~S}$ rRNA gene sequence similarity to $\mathrm{NF} 802^{\mathrm{T}}$ (1483 bp); NA, not applicable.

performed by the agar diffusion method on MuellerHinton agar and interpreted according to the guidelines of CLSI (2005).

Table 2 summarizes the biochemical data obtained. All strains of $C$. hominis were positive for oxidase and catalase activities, growth at 30 and $37{ }^{\circ} \mathrm{C}$ (with optimal growth at $30{ }^{\circ} \mathrm{C}$ ), aerobic growth, acid production from glucose, maltose and ethylene glycol, indole production, hydrolysis of aesculin, starch and gelatin, alkaline phosphatase, trypsin (benzylarginine arylamidase) and pyrrolidonyl-aminopeptidase (except for CCUG 36749) activities, and resistance to desferrioxamine. Acid production from sucrose, reduction of nitrate and nitrite, and hydrolysis of tyrosine were variable. Schreckenberger et al. (2003) reported positive nitrate reduction ( $90 \%$ ) in group II-c and a negative result in group II-h. However, in our series, four strains out of seven with a II-h profile also reduced nitrate. All strains were negative for production of flexirubin pigments, growth at $42{ }^{\circ} \mathrm{C}$, urease activity, $\mathrm{H}_{2} \mathrm{~S}$ production on Kligler agar, Tween 80 hydrolysis, ornithine and lysine decarboxylases, arginine dihydrolase, alkalinization of citrate on Simmons' agar and L-phenylalanine deaminase.

Phenotypically, C. hominis can be differentiated from Chryseobacterium hispanicum (Gallego et al., 2006) by growth at $37{ }^{\circ} \mathrm{C}$, lack of acid production from xylose and arabinose and positive alkalinization of acetate on Simmons' agar base, and from Chryseobacterium caeni by lack of acid production from arabinose, trehalose and xylose and absence of $\beta$-galactosidase (ONPG) activity. The absence of flexirubin pigments was a unique feature differentiating C. hominis from all other Chryseobacterium species. It should be noted that some of our results obtained with $C$. caeni were different from those of the original description (Quan et al., 2007). For C. caeni $\mathrm{N} 4^{\mathrm{T}}$, which was reported originally as being asaccharolytic, we detected acid production from several sugars by using oxidation-fermentation medium and phenol red agar with low peptone content (Wauters et al., 1998). The type strain of C. caeni produced indole on urea-indole broth and was urease-negative on Christensen's urea broth and ureaindole broth.

The 16S rRNA gene sequences were determined for all isolates as described previously (Wauters et al., 2003), and phylogenetic tree construction based on 16S rRNA gene sequences was done as described by Nemec et al. (2001). Cluster analysis was performed by using GeneBase (Applied Maths) and was based on the neighbour-joining method. The four CDC II-c strains were found to cluster together with the seven CDC II-h strains according to $16 \mathrm{~S}$ rRNA gene sequence similarity (Table 1; Fig. 1). This should not be surprising, as CDC II-c strains differ phenotypically from CDC II-h strains only by positive acidification of sucrose. The similarity of the type strain $(C$. hominis $\mathrm{NF} 802^{\mathrm{T}}$ ) to the other 10 strains ranged between 99.5 and $100 \%$. A strain submitted to GenBank as 'Chryseobacterium aquaticum' (accession no. AM398648) and isolated from the drinking-water distribution system of Sevilla, Spain, was found to have a sequence identical to those of four C. hominis strains (NF802 ${ }^{\mathrm{T}}$, NF696, CCUG 36748 and CCUG 15261). Based on 16S rRNA gene sequence, this collection of strains was related most closely to C. hispanicum (97.2\%). A maximum-parsimony tree showed essentially the same topology (data not shown).

For DNA-DNA hybridization, a microplate method was used, modified after Lind \& Ursing (1986) and described

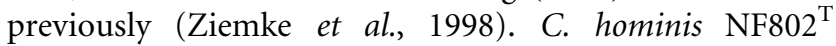
showed $>90 \%$ DNA-DNA similarity to strains CCUG 36748, CCUG 15261 and CCUG 13649, but only $57.8 \%$ DNA-DNA similarity to the type strain of C. hispanicum.

The DNA G + C content of the type strain, determined by HPLC at the Deutsche Sammlung von Mikroorganismen und Zellkulturen, Braunschweig, Germany, according to Mesbah et al. (1989), was $36.5 \mathrm{~mol} \%$.

Fatty acid analysis was carried out on cells grown for $48 \mathrm{~h}$ on tryptone soy agar at $28{ }^{\circ} \mathrm{C}$ as described previously 
Table 2. Phenotypic characteristics useful to differentiate C. hominis from related bacteria

Taxa: 1, C. hominis; 2, Chryseobacterium balustinum; 3, C. caeni; 4, Chryseobacterium defluvii; 5, Chryseobacterium formosense; 6, Chryseobacterium gleum; 7, C. hispanicum; 8, Chryseobacterium indologenes; 9, Chryseobacterium indoltheticum; 10, Chryseobacterium joostei; 11, 'Chryseobacterium proteolyticum'; 12, Chryseobacterium scophthalmum; 13, Chryseobacterium taichungense; 14, Elizabethkingia meningoseptica; 15, Elizabethkingia miricola. Data for C. hominis, C. hispanicum and C. caeni are from this study. Data for reference species were taken from de Beer et al. (2005), Kämpfer et al. (2003), Kim et al. (2005a, b), Li et al. (2003), Hugo et al. (2003), Park et al. (2006), Quan et al. (2007), Shen et al. (2005), Shimomura et al. (2005), Tai et al. (2006), Weon et al. (2006), Yamaguchi \& Yokoe (2000) and Young et al. (2005). +, All strains tested positive; (+), weakly positive; -, all strains tested negative; $\mathrm{v}$, variable; NA, not available.

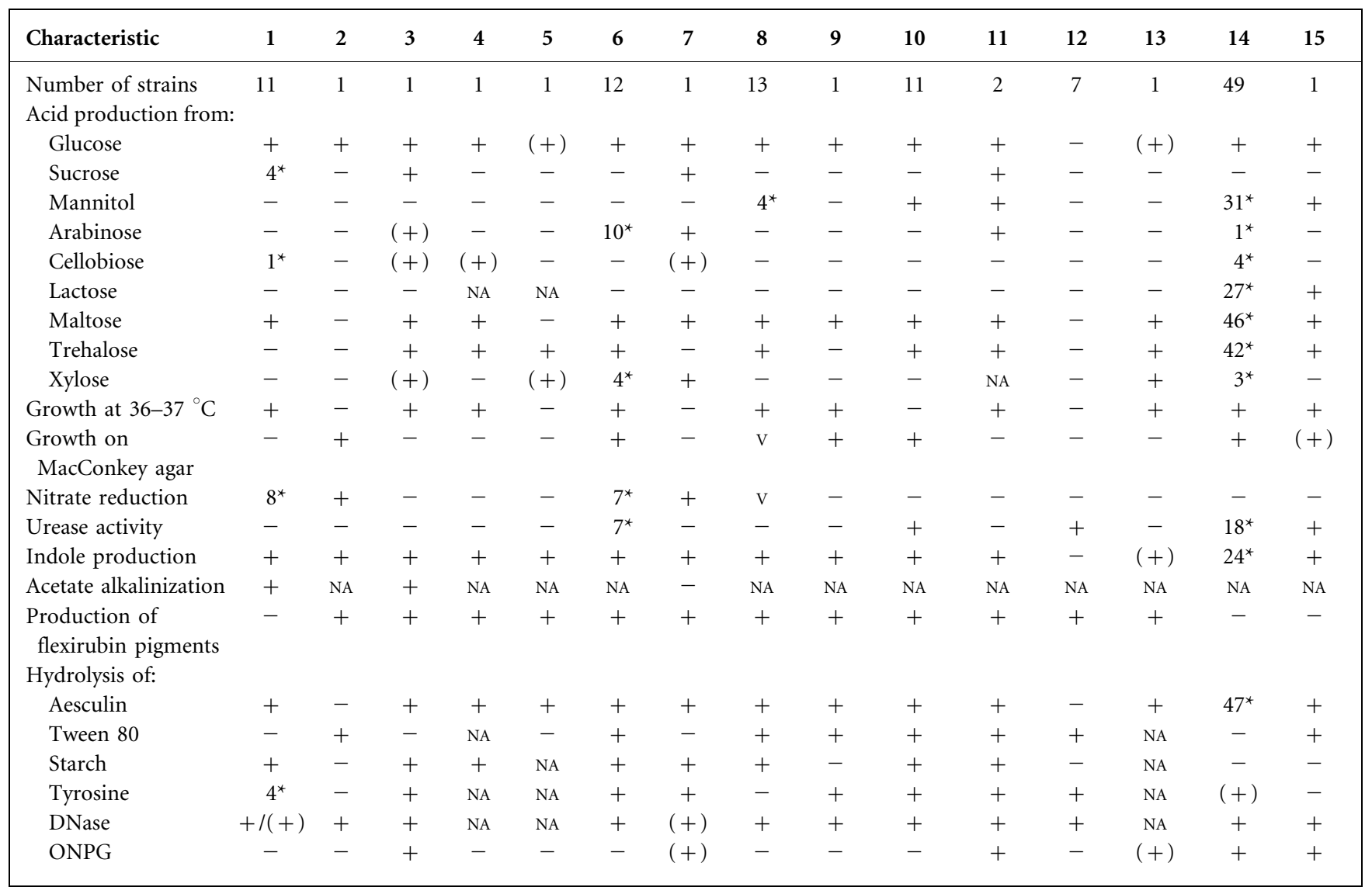

${ }^{\star}$ Number of positive strains.

(Kämpfer \& Kroppenstedt, 1996; Kämpfer et al., 2003). Table 3 compares the data obtained during this study for four $C$. hominis strains with those reported in the literature for related Chryseobacterium species.

tRNA-intergenic length polymorphism analysis (tDNAPCR) was carried out as described previously (Baele et al., 2000). The tDNA-PCR patterns of 10 C. hominis strains were compared with the pattern of the C. hispanicum type strain. All 11 strains had tRNA-intergenic spacers in common, with lengths of 57.6, 90.2, 91.3 and $92.3 \mathrm{bp}$. C. hominis had spacers of $81.1 \mathrm{bp}$ (compared with $82.9 \mathrm{bp}$ for C. hispanicum) and of 86.7, 89.3 and 110.6 bp that were absent in the type strain of $C$. hispanicum, whereas the latter had spacers of $94.5,138.8,232.0$ and $236.1 \mathrm{bp}$, not observed in any of the 10 C. hominis strains. On the basis of the data presented, the 11 strains should be assigned to the genus Chryseobacterium as representing a novel species, for which the name Chryseobacterium hominis sp. nov. is proposed.

\section{Description of Chryseobacterium hominis sp. nov.}

Chryseobacterium hominis (ho'mi.nis. L. gen. $\mathrm{n}$. hominis of a man, of a human being, named as such because most of the known isolates at the time of description are of human origin, in opposition to most other Chryseobacterium species).

Non-motile, Gram-negative rods, $1-3 \mu \mathrm{m}$ in length and $1.0-1.5 \mu \mathrm{m}$ in width, growing aerobically at 20,30 and $37{ }^{\circ} \mathrm{C}$ on standard media such as tryptic soy agar and blood agar, with optimal growth at $30^{\circ} \mathrm{C}$. No growth on MacConkey agar, cetrimide agar or $3 \% \mathrm{NaCl}$ agar. Colonies are circular and mucoid; some are also sticky. 


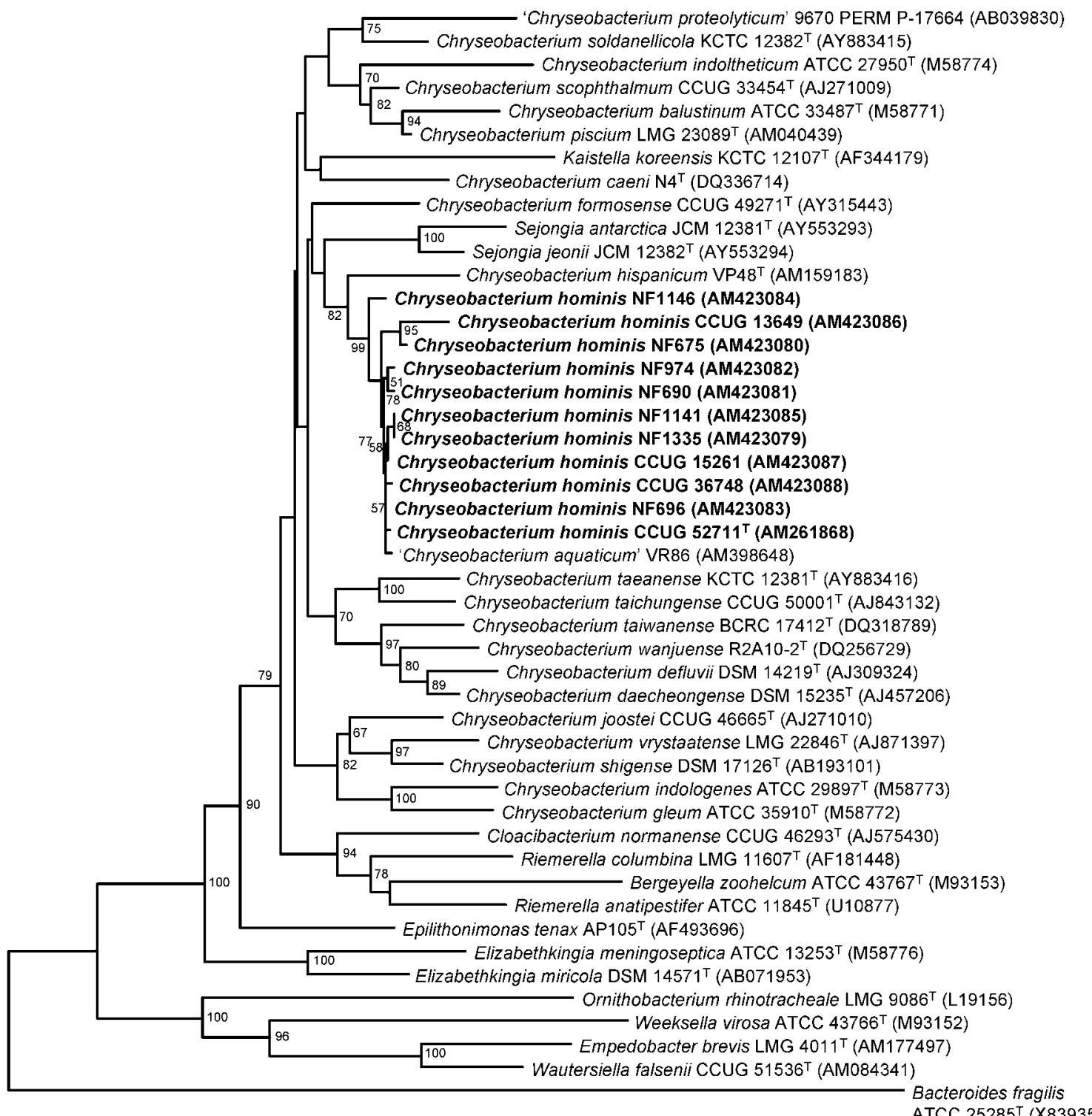

$2 \%$

Fig. 1. Neighbour-joining dendrogram of 16S rRNA gene sequences obtained from Chryseobacterium hominis and related species and genera. The 16S rRNA gene sequence of Bacteroides fragilis (GenBank accession no. X83935) was used as an outgroup. Bootstrap analysis values (from 100 resamplings) $>50 \%$ are shown at the branching points. Bar, $2 \%$ sequence dissimilarity.

Some strains exhibit a pale yellow or tan pigmentation, but no flexirubin pigments are produced. Acid is produced oxidatively from glucose, maltose and ethylene glycol. Acidification of sucrose is variable. Urease, lysine decarboxylase, ornithine decarboxylase and arginine dihydrolase activities are absent. Indole is produced. Acetate is alkalinized, but citrate is not. Aesculin and gelatin are hydrolysed. Reduction of nitrate is variable. Alkaline phosphatase and trypsin (benzylarginine arylamidase) activities are present, and pyrrolidonyl aminopeptidase activity is present in most strains. Other phenotypic characteristics are listed in Tables 2 and 3. The major cellular fatty acids are 15:0 iso, 17:0 iso $3-\mathrm{OH}, 17: 0$ iso $\omega 9 c$ and 15:0 anteiso. Strains are susceptible to tetracycline, ciprofloxacin and trimethoprim/cotrimoxazole and resistant to ampicillin and temocillin. Susceptibility is variable to cephalothin, cefotaxime, erythromycin, gentamicin and colistin.

The type strain, NF802 ${ }^{\mathrm{T}}\left(=\mathrm{CCUG} 52711^{\mathrm{T}}=\mathrm{CIP} 109415^{\mathrm{T}}\right)$, was isolated from the blood of a Belgian patient in 1998 . The DNA G + C content of the type strain is $36.5 \mathrm{~mol} \%$. 
Table 3. Long-chain fatty acid composition of $C$. hominis strains and related bacteria

Taxa: 1, C. hominis $\mathrm{NF} 82^{\mathrm{T}}$; 2, C. hominis CCUG 15261; 3, C. hominis CCUG 13649; 4, C. hominis CCUG 36748; 5, C. balustinum; 6, C. caeni $(n=1) ; 7, C$. defluvii $(n=1) ; 8$, C. formosense $(n=1) ; 9$, C. gleum $(n=5) ; 10$, C. hispanicum $(n=1) ; 11$, C. indologenes $(n=45) ; 12$, C. indoltheticum $(n=1) ; 13$; C. joostei $(n=11) ; 14$, C. scophthalmum $(n=2) ; 15$, C. taichungense $(n=1) ; 16$, E. meningoseptica $(n=5) ; 17, E$. miricola $(n=2)$. ' $C$. proteolyticum' is not listed, as no data are available. Values are percentages of total fatty acids. Fatty acids amounting to $<1 \%$ of the total fatty acids in all strains are not listed. Some of the strains/species were not cultivated under the same conditions. Where applicable, means $\pm \mathrm{SD}$ are given. Tr, Trace (<1.0\%); ND, not detected. Data are from de Beer et al. (2005), Hugo et al. (2003), Kämpfer et al. (2003), Kim et al. (2005a, b), Li et al. (2003), Park et al. (2006), Quan et al., (2007), Shen et al. (2005), Shimomura et al. (2005), Tai et al. (2006), Weon et al. (2006), Yamaguchi \& Yokoe (2000) and Young et al. (2005).

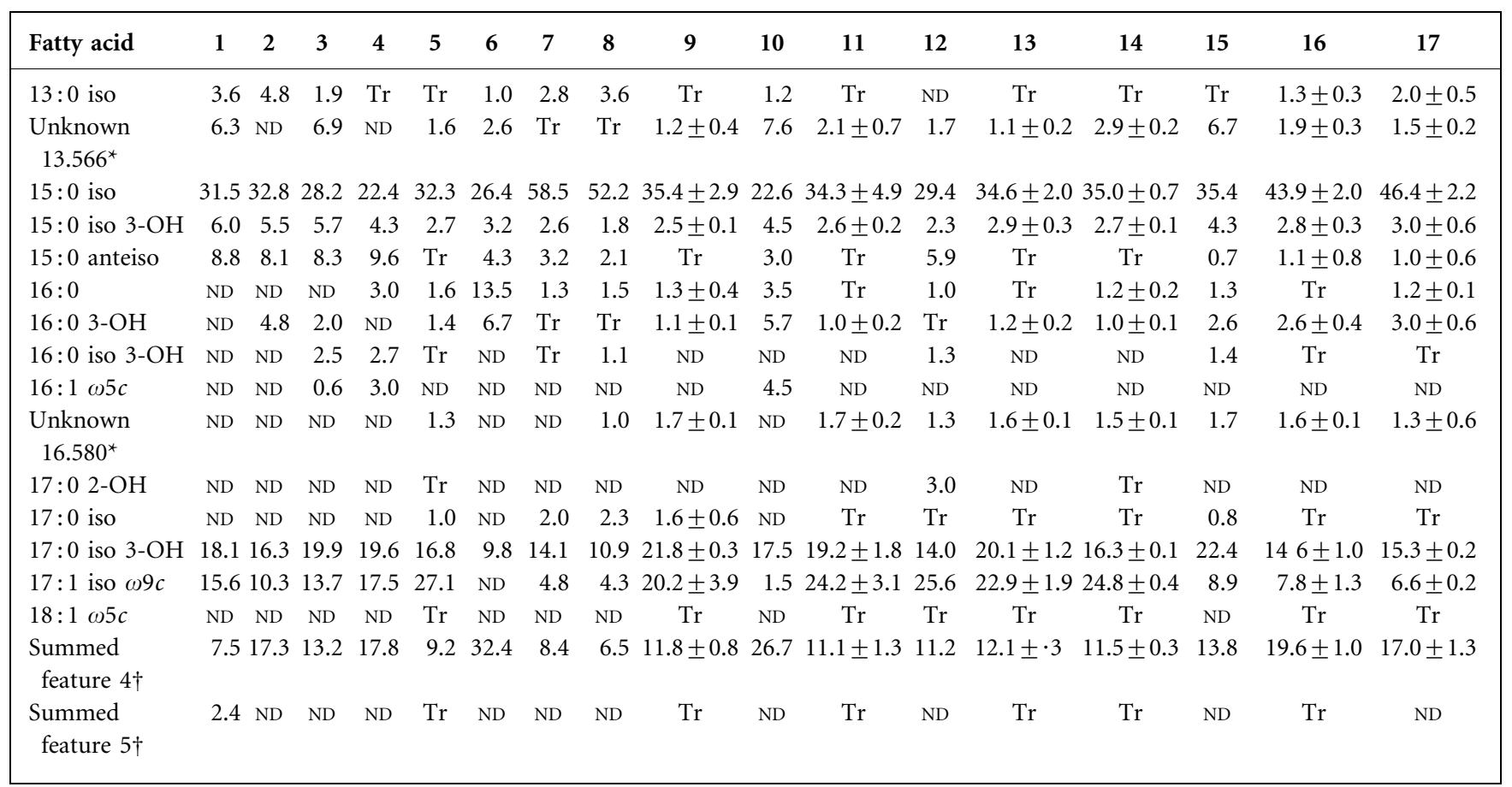

*Unknown fatty acid; number indicates equivalent chain length.

$\dagger$ Fatty acids that could not be separated by GC using the Microbial Identification (MIDI; Microbial ID) system: summed feature 4, 15:0 iso 2-OH and/or 16:1 $\omega 7 t$; summed feature 5, 17:1 iso I and/or 17:1 anteiso B.

\section{Acknowledgements}

We are grateful to Enevold Falsen for providing us with CCUG strains. The authors thank Leen Van Simaey and Catharine De Ganck for excellent technical assistance. T.D.B. is indebted to the Fonds voor Wetenschappelijk Onderzoek Vlaanderen (FWO) for his postdoctoral research grant.

\section{References}

Baele, M., Baele, P., Vaneechoutte, M., Storms, V., Butaye, P., Devriese, L. A., Verschraegen, G., Gillis, M. \& Haesebrouck, F. (2000). Application of tDNA-PCR for the identification of Enterococcus species. J Clin Microbiol 38, 4201-4207.

Bernardet, J.-F., Nakagawa, Y. \& Holmes, B. (2002). Proposed minimal standards for describing new taxa of the family Flavobacteriaceae and emended description of the family. Int J Syst Evol Microbiol 52, 1049-1070.

CLSI (2005). Performance Standards for Antimicrobial Susceptibility Testing (Approved Standard M100-S15). Wayne, PA: Clinical and Laboratory Standards Institute. de Beer, H., Hugo, C. J., Jooste, P. J., Willems, A., Vancanneyt, M., Coenye, T. \& Vandamme, P. A. (2005). Chryseobacterium vrystaatense sp. nov., isolated from raw chicken in a chicken-processing plant. Int J Syst Evol Microbiol 55, 2149-2153.

Gallego, V., Garcia, M. T. \& Ventosa, A. (2006). Chryseobacterium hispanicum sp. nov., isolated from the drinking water distribution system of Sevilla, Spain. Int J Syst Evol Microbiol 56, 1589-1592.

Hugo, C. J., Segers, P., Hoste, B., Vancanneyt, M. \& Kersters, K. (2003). Chryseobacterium joostei sp. nov., isolated from the dairy environment. Int J Syst Evol Microbiol 53, 771-777.

Kämpfer, P. \& Kroppenstedt, R. M. (1996). Numerical analysis of fatty acid patterns of coryneform bacteria and related taxa. Can J Microbiol 42, 989-1005.

Kämpfer, P., Dreyer, U., Neef, A., Dott, W. \& Busse, H.-J. (2003). Chryseobacterium defluvii sp. nov., isolated from wastewater. Int J Syst Evol Microbiol 53, 93-97.

Kämpfer, P., Avesani, V., Janssens, M., Charlier, J., De Baere, T. \& Vaneechoutte, M. (2006). Description of Wautersiella falsenii gen. nov., sp. nov., to accommodate clinical isolates phenotypically resembling members of the genera Chryseobacterium and Empedobacter. Int J Syst Evol Microbiol 56, 2323-2329. 
Kim, K. K., Bae, H. S., Schumann, P. \& Lee, S. T. (2005a). Chryseobacterium daecheongense sp. nov., isolated from freshwater lake sediment. Int J Syst Evol Microbiol 55, 133-138.

Kim, K. K., Kim, M. K., Lim, J. H., Park, H. Y. \& Lee, S. T. (2005b). Transfer of Chryseobacterium meningosepticum and Chryseobacterium miricola to Elizabethkingia gen. nov. as Elizabethkingia meningoseptica comb. nov. and Elizabethkingia miricola comb. nov. Int J Syst Evol Microbiol 55, 1287-1293.

Laffineur, K., Janssens, M., Charlier, J., Avesani, V., Wauters, G. \& Delmée, M. (2002). Biochemical and susceptibility tests useful for identification of nonfermenting Gram-negative rods. J Clin Microbiol 40, 1085-1087.

Li, Y., Kawamura, Y., Fujiwara, N., Naka, T., Liu, H., Huang, X., Kobayashi, K. \& Ezaki, T. (2003). Chryseobacterium miricola sp. nov., a novel species isolated from condensation water of space station Mir. Syst Appl Microbiol 26, 523-528.

Lind, E. \& Ursing, J. (1986). Clinical strains of Enterobacter agglomerans (synonyms: Erwinia herbicola, Erwinia milletiae) identified by DNA-DNA-hybridization. Acta Pathol Microbiol Immunol Scand [B] 94, 205-213.

Martin, R., Riley, P. S., Hollis, D. G., Weaver, R. E. \& Krichevsky, M. I. (1981). Characterization of some groups of Gram-negative nonfermentative bacteria by the carbon source alkalinization technique. J Clin Microbiol 14, 39-47.

Mesbah, M., Premachandran, U. \& Whitman, W. B. (1989). Precise measurement of the $\mathrm{G}+\mathrm{C}$ content of deoxyribonucleic acid by highperformance liquid chromatography. Int J Syst Bacteriol 39, 159-167.

Nemec, A., De Baere, T., Tjernberg, I., Vaneechoutte, M., van der Reijden, T. J. K. \& Dijkshoorn, L. (2001). Acinetobacter ursingii sp. nov. and Acinetobacter schindleri sp. nov., isolated from human clinical specimens. Int J Syst Evol Microbiol 51, 1891-1899.

Park, M. S., Jung, S. R., Lee, K. H., Lee, M. S., Do, J. O., Kim, S. B. \& Bae, K. S. (2006). Chryseobacterium soldanellicola sp. nov. and Chryseobacterium taeanense sp. nov., isolated from roots of sand-dune plants. Int J Syst Evol Microbiol 56, 433-438.

Quan, Z.-X., Kim, K. K., Kim, M.-K., Jin, L. \& Lee, S. T. (2007). Chryseobacterium caeni sp. nov., isolated form bioreactor sludge. Int $J$ Syst Evol Microbiol 57, 141-145.
Schreckenberger, P. C., Daneshvar, M. I., Weyant, S. R. \& Hollis, D. G. (2003). Acinetobacter, Achromobacter, Chryseobacterium, Moraxella, and other nonfermentative Gram-negative rods. In Manual of Clinical Microbiology, 8th edn, pp. 749-779. Edited by P. R. Murray, E. J. Baron, J. H. Jorgensen, M. A. Pfaller \& R. H. Yolken. Washington, DC: American Society for Microbiology.

Shen, F. T., Kämpfer, P., Young, C. C., Lai, W. A. \& Arun, A. B. (2005). Chryseobacterium taichungense sp. nov., isolated from contaminated soil. Int J Syst Evol Microbiol 55, 1301-1304.

Shimomura, K., Kaji, S. \& Hiraishi, A. (2005). Chryseobacterium shigense sp. nov., a yellow-pigmented, aerobic bacterium isolated from a lactic acid beverage. Int J Syst Evol Microbiol 55, 1903-1906.

Tai, C. J., Kuo, H. P., Lee, F. L., Chen, H. K., Yokota, A. \& Lo, C. C. (2006). Chryseobacterium taiwanense sp. nov., isolated from soil in Taiwan. Int J Syst Evol Microbiol 56, 1771-1776.

Wauters, G., Van Bosterhaut, B., Janssens, M. \& Verhaegen, J. (1998). Identification of Corynebacterium amycolatum and other nonlipophilic fermentative corynebacteria of human origin. J Clin Microbiol 36, 1430-1432.

Wauters, G., Avesani, V., Laffineur, K., Charlier, J., Janssens, M., Van Bosterhaut, B. \& Delmée, M. (2003). Brevibacterium lutescens sp. nov., from human and environmental samples. Int $J$ Syst Evol Microbiol 53, 1321-1325.

Weon, H. Y., Kim, B. Y., Yoo, S. H., Kwon, S. W., Cho, Y. H., Go, S. J. \& Stackebrandt, E. (2006). Chryseobacterium wanjuense sp. nov., isolated from greenhouse soil in Korea. Int J Syst Evol Microbiol 56, 1501-1504.

Yamaguchi, S. \& Yokoe, M. (2000). A novel protein-deamidating enzyme from Chryseobacterium proteolyticum sp. nov., a newly isolated bacterium from soil. Appl Environ Microbiol 66, 3337-3343.

Young, C. C., Kämpfer, P., Shen, F. T., Lai, W. A. \& Arun, A. B. (2005). Chryseobacterium formosense sp. nov., isolated from the rhizosphere of Lactuca sativa L. (garden lettuce). Int J Syst Evol Microbiol 55, 423-426.

Ziemke, F., Höfle, M. G., Lalucat, J. \& Rosselló-Mora, R. (1998). Reclassification of Shewanella putrefaciens Owen's genomic group II as Shewanella baltica sp. nov. Int J Syst Bacteriol 48, 179-186. 